\title{
Ethics briefing
}

Veronica English, Jessica Gardner, Gillian Romano-Critchley, Ann Sommerville Medical Ethics Department, British Medical Association

\section{Legal prohibition on procreation}

The election of George Bush heralded a shift to the right in American politics and with it the expectation of a more conservative approach to issues such as abortion. In an interesting twist, however, the Wisconsin Supreme Court has upheld a decision that has been described as potentially "coercive of abortion". David Oakley, a father of nine children with four different mothers was found guilty of intentionally refusing to pay child support and was sentenced to three years in prison followed by five years' probation. As a condition of his probation, Oakley cannot have any more children unless he demonstrates that he has the ability to support them and that he is supporting the children he already has. Failure to comply with the conditions of the probation would result in a further eight years' imprisonment. Oakley argued that the condition violated his right to procreate, since he was unlikely ever to be able to support all of his children, but his appeal was rejected. The majority decision held that, since the conditions were "not overly broad" and were "reasonably related to the person's rehabilitation", the conditions of probation could legitimately impinge upon constitutional rights. In dissenting from the majority decision, Ann Walsh Bradley, J stated: "[b]ecause the condition is triggered only upon the birth of a child, the risk of imprisonment creates a strong incentive for a man in Oakley's position to demand from the woman the termination of her pregnancy. It places the woman in an untenable position: have an abortion or be responsible for Oakley going to prison for eight years".

One commentator has pointed out that, in this case, "one precept of rightwing politics-that the state should not pay for the upkeep of offspring irresponsibly acquired-has come into conflict with another: that normal healthy people should have as many children as possible". He goes on to say that this presents a dilemma for Republicans since "it is now legal for Mr Oakley to have a child of his aborted, but not to allow it to be born".

\section{Abortion in Northern Ireland}

In June, the Family Planning Association (FPA) was granted leave for a judicial review of the practice of abortion in Northern Ireland. The application is not to amend the law but to require the health minister to issue best practice guidelines for the medical profession and advice to women on the services available. ${ }^{3}$

The Abortion Act 1967, which governs abortion in Great Britain does not extend to Northern Ireland where the law is based on the Offences Against The Person Act 1861 which makes it an offence to "procure a miscarriage unlawfully". Although some abortions are carried out in Northern Ireland, and legal cases in $1939^{4}$ and the early $1990 \mathrm{~s}^{5}$ have given some clarification of the circumstances in which abortion is lawful, the FPA has argued that the lack of clear guidance has resulted in "confusing and inconsistent medical practice". 6

\section{'Wrongful life' claims}

The Cour de Cassation, France's highest court of appeal, ruled in July 2001 that the parents of handicapped children are entitled to compensation for being denied the option of seeking an abortion. ${ }^{7}$ It examined the cases of three handicapped children whose malformations had not been detected at the time of pregnancy. One child was born with spina bifida and two were born with malformations of upper limbs. Had the disabilities been detected in the first ten weeks of pregnancy, under French law the women could have opted for a voluntary termination. After that time, two doctors must be satisfied that there are therapeutic grounds for terminating the pregnancy. This affirmed an earlier decision, known as the Perruche case. ${ }^{8}$

These cases are significant because many other jurisdictions, including England, the United States and Australia have persistently failed to recognise so-called "wrongful life claims". Most United States courts, ${ }^{9}$ for example, have refused claims on two grounds: that there is no legally cognisable injury and that it is impossible to assess damages, since this would entail compensating the child on the grounds that he or she would have been better off not being born. Similarly, in England the Court of Appeal ${ }^{10}$ rejecting the claim made on behalf of a child born suffering from the effects of antenatal rubella, found that the disabilities were caused by the rubella and not by the doctor "the compensation must be based on a comparison between the value of nonexistence (the doctor's alleged negligence having deprived her of this) and the value of her existence in a disabled state. But how can a court begin to evaluate non-existence . . ? No comparison is possible and therefore no damage can be established which a court could recognise". ${ }^{11}$

(See the supplement to this issue of the journal: The New Ethics of Abortion.)

\section{Alcohol, drugs and driving}

There has been increasing interest in the UK in recent years about prosecutions for driving under the influence of alcohol or other drugs. Many people see it as problematic that the UK law only allows drivers who give consent to have forensic tests to determine their levels of alcohol or other drugs. This means that unconscious or otherwise incapacitated drivers who have been involved in an accident cannot be given these forensic tests and may avoid prosecution for driving under the influence of drugs for lack of evidence. 
In other jurisdictions, the law does allow these tests to be done without consent. As part of its road safety strategy, for example, New South Wales has a compulsory blood alcohol testing policy which requires a doctor or nurse to take a blood sample from a driver or pedestrian who is involved in an accident, and it is an offence not to do so. In Victoria there is a statutory requirement on drivers who have been involved in accidents to allow a doctor to take a blood sample and the Victorian Emergency Department Association publishes a code of practice for taking the samples.

The Home Office is considering law reform to solve these problems in the UK. At present, taking a blood sample from a patient without consent in order to carry out forensic testing is likely to constitute the offence of battery. Individual members of parliament have, in the past, campaigned for a change in the law, but have always been unsuccessful. The UK government is now considering its own proposals that would allow a specially authorised police surgeon to take a blood sample from a patient who lacks capacity and for the sample to be tested for alcohol and/or other drugs. The medical profession has always resisted expressing a view on the appropriateness of such legislative change, but the British Medical Assocation (BMA) has recently made policy supporting a change in the law to allow blood samples to be taken without consent to prevent people who drive under the influence of alcohol or other drugs from evading appropriate prosecution.

\section{Doctors and the death penalty}

In countries practising capital punishment, lethal injection by doctors is increasingly seen as the most reliable method. The USA is the most prolific user and lethal injection by doctors has been used there since the early 1980s. By 1998, it was the sole method of execution in 21 American states and one of two options in 12 more.
Although lethal injection is only one facet of medical involvement in judicial punishments, it has probably attracted most attention.

In 1981, the World Medical Association condemned involvement by doctors in any form of capital punishment but medical organisations have generally refrained from broaching the more general question of the acceptability of the death penalty as such. This changed in July 2001 when the BMA passed a resolution opposing any use of the death penalty worldwide, contrary to earlier views that it was inappropriate for a medical organisation to make policy on social issues abroad. The resolution followed growing concern about the manner in which capital punishment had been applied in the USA to people with impaired mental capacity, to a disproportionate number of black offenders and to people who were juveniles at the time of the offence. Three years previously, in 1998, the BMA's annual meeting rejected any involvement of doctor "either directly or indirectly" in implementing the death penalty. Problem arose, however, in precisely defining "indirect involvement". Some had argued at the 1998 meeting that providing medical evidence in a capital trial, assessing a prisoner's mental capacity or future dangerousness or providing essential medical treatment to a sick prisoner on death row in order to render that person "fit for punishment" could be seen as facilitating the death penalty. In 2001, in its report The Medical Profession and Human Rights ${ }^{12}$ the BMA predicted that medical organisations would eventually need to address the larger moral issues inherent in capital punishment since regardless of whether doctors actually gave lethal injections, medical knowledge and techniques were increasingly employed. As yet the BMA seems to be the only one to have gone this far.

\section{Defining 'best interests'}

For at least a decade the UK Lord Chancellor's Department has been considering the need for reform of the law that protects mentally incapacitated adults and authorises medical treatment for people who cannot give consent. Two consultation exercises, in 1995 and 1997 , led to the publication of proposals for law reform in October 1999, but as yet there have been no moves to introduce legislation and there is no time allocated to do so this parliamentary session.

To fill the hiatus, and as part of a programme of policy development prior to the introduction of a bill, the Lord Chancellor's Department is bringing together interested groups to draft a code of practice to cover the areas where guidance is most urgently needed. Defining "best interests" and explaining the legally binding nature of advance directives will be two aspects of this. A consultation draft is expected in October 2001.

\section{References and notes}

1 State of Wisconsin v David W Oakley, 2001, 239 Wis 2d 235, 619 NW2d 308

2 Lawson M. Rewriting the rules of procreation The Guardian 2001 Jul 14: 20.

3 Payne D. Abortion in Northern Ireland to be reviewed. British Medical fournal 2001;322:1507.

$4 R$ v Bourne [1939] $1 \mathrm{~KB} 687$; [1938] 3 All ER 615.

5 Lee S. An A to $Z$ to $K$ of abortion law in Northern Ireland: abortion on remand. In: Furedi A, ed. The abortion law in Northern Ireland. Lavenham: Family Planning Association Northern Family Plan HEE1293, 1995.

6 BBC News Online. Abortion law to be reviewed. 2001 Jun 13. http:// news.bbc.co.uk.

7 BBC News Online. France upholds right not to be born. $2001 \mathrm{Jul13}$. http:// news.bbc.co.uk

8 BBC News Online. Boy compensated for being born. 2000 Nov 17. http:// news.bbc.co.uk.

9 Becker v Shwartz 413 NYS 2d 895, 900 (1978)

10 Mackay $v$ Essex Health Authority [1982] 1 QB 1166.

11 See reference 10: 1189.

12 British Medical Association. The medical profession and human rights. London: Zed Books, 2001: ch 7. 